\title{
RETIREMENT OF GERALD SELIGMAN AS EDITOR
}

Gerald Seligman's retirement from his editorship of the fournal of Glaciology is an appropriate occasion to pay tribute to his dedicated service. In 1936 he founded the Association for the Study of Snow and Ice to form a British group within the International Commission of Snow. After the war years he was the moving spirit in founding the British Glaciological Society as the successor to the Association, and he remained its President from I945 until r963, by which time it had assumed its present international form under the name of the Glaciological Society. The publishing of the Fournal has always been the main activity of the Society. The Zeitschrift für Gletscherkunde had lapsed during the war, and in 1947 on Seligman's initiative the fournal of Glaciology was launched, helped by the backing of the Scott Polar Research Institute and the Royal Society. It was jointly edited by Gerald Seligman, Launcelot Fleming, Brian Roberts and Robert Moss until the fourth number in October I 948 when Seligman became Editor and the others an Advisory Editorial Committee. He has continued as Editor, at first with various assistants and later as senior editor on the Editorial Board, until the present issue.

The fournal is exactly twenty-one years old as Seligman retires. With fatherly care he has watched it grow from infancy to its present secure position. "Watched" is not the right word if it gives an impression of inactivity. On the contrary, a scientific periodical does not flourish automatically; it needs constant attention and the exercise of good judgement. Most fortunately for us Seligman's concern for the development of the fournal has been devoted and unceasing, and, as a result, we in the glaciological community find ourselves with a journal of high scientific and editorial standards well suited to our needs. We should not take this for granted; we should recognise how it has been achieved. As Gerald Seligman retires from his editorship we give him our sincere thanks and we send him our best wishes for the future.

J. F. NYE 